\title{
Antibiofilm activity of symbiotic Bacillus species associated with marine gastropods
}

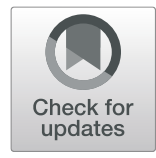

Nadarajan Viju ${ }^{*^{*}}$ (D), Satniuslas Mary Josephine Punitha ${ }^{1}$ and Sathianeson Satheesh ${ }^{2}$ (D)

\begin{abstract}
Purpose: Generally, symbiotic marine bacteria are renowned for the synthesis of compounds with bioactive properties, and this has been documented in many previous studies. Therefore, the present study was aimed to isolate novel bacterial symbionts of gastropods that have the ability to synthesize bioactive compounds. These bioactive compounds could be used effectively as antibiofilm agents in order to overcome the problems associated with biofilm.

Methods: The bacteria associated with the surface of marine gastropods were isolated and characterized. Following this, the bacterial metabolites were extracted and their antibiofilm effect was evaluated on biofilm-forming bacteria on artificial substrates. Moreover, the biofilm-forming bacterium Alteromonas sp. was treated with the extracts of symbiotic bacteria in order to evaluate the influence of extracts over the synthesis of extracellular polymeric substance (EPS). Besides, the biologically active chemical constituents of the extracts were separated using thin-layer chromatography and subjected to gas chromatography and mass spectrometry (GC-MS) analysis for characterization.

Results: Three bacterial strains belonging to the species Bacillus firmus, Bacillus cereus and Bacillus subtilis were identified from the bacterial community associated with the gastropods. The antibiofilm assays revealed that the extract of three symbiotic bacteria significantly $(p<0.05)$ reduced the biofilm formation by the marine bacterium Alteromonas sp. on artificial materials. Also, the EPS synthesis by Alteromonas sp. was significantly inhibited due to symbiotic bacterial extract treatment. The chemical composition of the bioactive fraction isolated from the symbiotic bacteria extract revealed that most of the detected compounds were belonging to aromatic acid, fatty acid and carboxylic acid.
\end{abstract}

Conclusion: The results of this study clearly revealed that the bacteria belonging to the above listed Bacillus species can be considered as a promising source of natural antibiofilm agents.

Keywords: Biofilm, Symbiotic bacteria, Bacillus species, Marine natural products, Antibacterial activity, Antibiofilm activity

\section{Introduction}

Microorganisms generally occur in the environment as a community known as biofilm able to grow on abiotic and biotic surfaces. Most of the microorganisms found in the environment prefer biofilm mode of life, as biofilm enhances the survival and metabolism of microbes during adverse conditions (Ikuma et al., 2013). Biofilm can exist on all kinds of surfaces such as plastics, metal, glass, soil particles, wood, medical implants, food products and tissues. Biofilm is a serious problem in many fields such as medical industries, food industries and

\footnotetext{
* Correspondence: vijuuu333@gmail.com

${ }^{1}$ CMST, M.S. University, Tirunelveli, Tamilnadu, India

Full list of author information is available at the end of the article
}

paper industries (Campoccia et al., 2006; Chen et al., 2007; Lopez et al., 2010; Francolini and Donelli, 2010; Hoiby et al., 2011). Moreover, biofilm has a drastic impact on the marine industries, where biofilm accelerates the corrosion and facilitates the rapid development of biofouling (accumulation of macrofoulers) on the surface of underwater objects developed by human beings (Little et al., 2008, Cao et al., 2011). Notably, the annual economic loss caused by biofilm in the marine industries has been estimated as 2.5 trillion dollars (Koch et al., 2016), while the economic loss due to biofilm in the health care sector is about 77.7 billion dollars (Khelissa et al., 2017).

(C) The Author(s). 2020 Open Access This article is distributed under the terms of the Creative Commons Attribution 4.0 International License (http://creativecommons.org/licenses/by/4.0/), which permits unrestricted use, distribution, and reproduction in any medium, provided you give appropriate credit to the original author(s) and the source, provide a link to the Creative Commons license, and indicate if changes were made. 
The chemical antifouling biocides were widely used to overcome the problems connected with biofilm, but the consistent usage led to the development of resistance among the biofilm-forming microbes and also these biocides were found to be toxic to the environment (Simoes and Vieira, 2009). In this circumstance, for controlling the biofilms on structures submerged in marine waters, environmentally friendly antibiofilm molecules were considered as highly valuable and alternative to the chemical antibiofilm agents (Donlan, 2009; Estrella et al., 2009). The bioactive molecules derived from the marine organisms are non-toxic or less toxic and biodegradable, and also the negative (toxic) effects may be less compared to the chemical antifouling compounds currently in practice (Satheesh et al., 2016). The antibiofilm properties of natural products obtained from various biological sources including marine bacterial symbionts have been well recorded (Papa et al., 2015; Camesi et al., 2016; Jun et al., 2018). For instance, the polysaccharide (A101) synthesized by the symbiotic marine bacterium Vibrio sp. has been reported to inhibit or disrupt the biofilm formation of pathogenic bacteria (Jiang et al., 2011). Many previous studies have also proved that the bacterial symbionts of marine macroorganisms have the ability to synthesize a high proportion of compounds that have biological activities (Viju et al., 2016; Alvarado et al., 2018). In the current research, the antibiofilm activity of the bacterial (Bacillus species) symbionts of marine gastropods was assessed against biofilm-forming bacteria.

\section{Materials and methods}

\section{Gastropod collection and isolation of their bacterial symbionts}

Gastropod samples were collected from three stations such as Thengapattanam (Arabian sea-South-west coast, $8^{\circ}$ $29^{\prime} \mathrm{N}$ and $77^{\circ} 32^{\prime} \mathrm{E}$ ), Colachel (Arabian sea-South-west coast, $8^{\circ} 17^{\prime} \mathrm{N}$ and $77^{\circ} 26^{\prime} \mathrm{E}$ ) and Kanyakumari (Gulf of Mannar-South-east coast, $8^{\circ} 26^{\prime} \mathrm{N}$ and $77^{\circ} 19^{\prime} \mathrm{E}$ ) along the intertidal region of Kanyakumari coast, India. The commonly available gastropod species such as Babylonia, Busycon, Collisella, Conus, Murex, Snar, Turbo and Turritella were collected and brought to the laboratory. The bacterial symbionts of gastropods were scraped off using a sterile nylon brush and suspended in $1 \mathrm{ml}$ filter-sterilized seawater. Following this, the agar spread plate method was used for the cultivation of symbiotic bacteria. For this, the bacterial suspension was serially diluted and spread around the Zobell marine agar (ZMA) plate (HIMEDIA, India) and the plate was then put away in a sterile chamber (at room temperature for $24 \mathrm{~h}$ ) for the cultivation of bacterial colonies. Subsequently, the cultivated bacterial colonies were isolated individually using the quadrant streak plate method described by Viju et al. (2018). The isolated bacterial colonies were classified based on their morphological characters and reserved on ZMA slant for further studies.

\section{Screening of bioactive bacteria}

The agar over-layer method explained by Anand et al. (2006) was used to analyse the synthesis of biologically active substances by bacterial symbionts of gastropods. For this, bacterial colonies were allowed to grow on the ZMA plate at room temperature for $24 \mathrm{~h}$. Following this, a soft agar medium was composed by suspending $0.6 \%$ of agar in Zobell marine broth (ZMB). This soft agar was then added with $10 \%$ of target bacterium Alteromonas sp. (biofilm-forming bacterium isolated by Satheesh et al. (2012)) and mixed properly. After that, the medium was poured on the symbiotic bacteria grown on the ZMA plate and incubated at room temperature. Twenty-four hours later, the antagonistic effect was analysed by observing the inhibition zone that appeared around the colonies of symbiotic bacteria. The selected bioactive bacteria were tentatively identified up to the genus level using the data obtained from the morphological and biochemical analysis (Delfan et al., 2012).

\section{Isolation of bioactive bacteria}

The bioactive bacteria were grown in the marine bacterial culture medium (ZMB) for a period of 5 days at room temperature $(28 \pm 1)$. After that, the bacterial cell pellet was separated from the culture medium by centrifugation and soaked in methanol for $72 \mathrm{~h}$ and the metabolites were extracted using the method explained by Viju et al. (2018). Following this, the antibacterial activity of the extract of symbiotic bacteria (ESB) was tested against biofilm-forming bacterium Alteromonas sp. using the agar disc diffusion method. In brief, a 6-mm sterile disc (HIMEDIA) was loaded with the ESB (50 mg of extract was dissolved in $2.5 \mathrm{ml}$ of DMSO), while a control disc was prepared by loading DMSO in place of ESB. Subsequently, the overnight culture of the target biofilmforming bacterium Alteromonas sp. was applied on the surface of Muller-Hinton agar plate. The plate was kept in an incubator at normal room temperature, and the antibacterial potential of the ESBs was assessed with the zone that appeared around the discs after $24 \mathrm{~h}$ of incubation (Shankar et al., 2015).

\section{Identification of bioactive bacterial symbionts}

The 16S rRNA gene of the symbiotic bioactive bacteria was isolated by the phenol-chloroform method (Satheesh et al. 2012). In brief, the cell pellet of the overnight culture of symbiotic bacteria was obtained by centrifugation (700 $\mathrm{r} \mathrm{min}^{-1}$ for $10 \mathrm{~min}$ ). The cell pellet was suspended in sucrose TE buffer $(400 \mu \mathrm{l})$ and added with the lysozyme at a concentration of $8 \mathrm{mg} / \mathrm{ml}$. An hour later, the enzyme proteinase $\mathrm{K}$ was added up and put 
away in an incubator (at $55{ }^{\circ} \mathrm{C}$ ) for $24 \mathrm{~h}$. After incubation, the lysate solution was added up with an equal volume of phenol-chloroform (1:1) solution and mixed properly. This solution was then centrifuged (10000 r $\mathrm{min}^{-1}$ for $10 \mathrm{~min}$ ), and the collected supernatant was added with chloroform-isoamylalcohol (24:1) and mixed up properly. After that, an adequate amount of ethanol was added and kept away for the precipitation of $16 \mathrm{~S}$ rRNA. The precipitate (rRNA) was isolated and amplified in the PCR using the universal primers, $27 \mathrm{f}\left(5^{\prime}-\right.$ AGAGTTTGATCCTGGCTCAG-3') and 1492r (5'GGTTACCTTGTTACGACTT-3'). The PCR reaction steps such as denaturation (at $95{ }^{\circ} \mathrm{C}$ for $30 \mathrm{~s}$ ), annealing (at $52{ }^{\circ} \mathrm{C}$ for $30 \mathrm{~s}$ ) and extension (at $60{ }^{\circ} \mathrm{C}$ for $4 \mathrm{~min}$ ) were carried out until the production of an adequate number of nucleotides (bps). The obtained sequence was analysed using the Basic Local Alignment Search Tool (BLAST), and their similarity was compared with the other bacterial sequences available in the National Center for Biotechnology Information (NCBI) (Viju et al., 2017). The sequence data of all the three symbiotic bacteria (B. firmus, B. cereus and B. subtilis) were deposited in GenBank, and their accession numbers have been assigned by NCBI. Subsequently, the evolutionary phylogenetic tree of the three bacteria was constructed along with the other 17 bacterial sequences belonging to Bacillus sp. obtained from NCBI using neighbour-joining method. The evolutionary distances were computed using the Tamura-Nei method with 2000 bootstrap replicates, and the analysis was carried out in MEGA 7 (Kumar et al., 2016).

\section{Preparation of biofilm bacterial cell suspension for laboratory bioassay}

To evaluate the antibiofilm effect of ESBs, bacterial cell suspension (BCS) was prepared with the target bacterium Alteromonas sp. For this, the cell pellet of the overnight culture of Alteromonas sp. was isolated by centrifugation (5000 rpm/15 min) and washed with phosphate buffer saline (PBS). A portion of the pellet was suspended in PBS, and its final concentration (optical density) was made up to 0.2 at $540 \mathrm{~nm}$ using a spectrophotometer.

\section{Antibiofilm assays of ESB \\ Antibiofilm effect of ESB on hydrophobic surface}

The microtiter plate was used as the hydrophobic surface to analyse the antibiofilm effect of ESB using the method explained by Ghaima et al. (2013). Two hundred microlitres of BCS and $20 \mu \mathrm{l}$ of ESB were taken in a microtiter plate (TARSONS) and mixed properly with a micropipette. At the same time, $20 \mu \mathrm{l}$ of DMSO was used in place of ESB for the preparation of control well and the plate was placed in an incubator at room temperature. Following $24 \mathrm{~h}$ of incubation, the liquid content of the well along with unattached bacteria was discarded and the well was washed with PBS ( $\mathrm{pH}$ 7.4). Subsequently, the bacteria (biofilm) attached to the surface were dyed with crystal violet $(0.1 \%)$ for a minute. Finally, the density of the biofilm developed on the well was evaluated with the ELISA reader at a wavelength of $570 \mathrm{~nm}$.

\section{Antibiofilm effect of ESB on hydrophilic surface}

The glass test tube was used as the hydrophilic surface to analyse the antibiofilm effect of ESB (Ghaima et al., 2013). In brief, the tubes (Borosil: $15 \times 125 \mathrm{~mm}$ ) containing sterilized ZMB medium $(3 \mathrm{ml})$ were added with $3 \mathrm{ml}$ of BCS and $0.5 \mathrm{ml} \mathrm{ESB}(0.5 \mathrm{ml}$ of DMSO was added in control tube). Subsequently, the content of the tube was mixed properly and the tubes were placed in a shaker at room temperature. Following $72 \mathrm{~h}$ of incubation, the content of the tubes was thrown out and flooded with PBS in order to clear up the unattached bacteria. Then the tubes were air-dried and the biofilm formed on the surface was dyed with crystal violet for a minute. And then, the unbounded dye was removed with PBS and the dye absorbed by the biofilm was retrieved with acetic acid and its density was evaluated using a spectrophotometer at $595 \mathrm{~nm}$.

\section{Influence of ESB on the synthesis of EPS by biofilm- forming bacterium}

The influence of ESB on the synthesis of EPS was calculated by estimating the carbohydrate and protein concentration of the extracellular polymeric substance. A test tube containing $3 \mathrm{ml}$ of BCS of Alteromonas sp. was treated with $0.5 \mathrm{ml}$ of ESB by keeping at shaker set up at room temperature. Following $24 \mathrm{~h}$ of incubation, the EPS synthesized by Alteromonas sp. on the ZMB medium was isolated using the method outlined by Viju et al. (2018). Subsequently, the carbohydrate and protein concentration of the isolated EPS was analysed by the procedures proposed by Dubois et al. (1956) and Lowry et al. (1951) respectively. The glucose was used as the standard for carbohydrate estimation, while bovine serum was used as the standard for protein estimation.

\section{Chromatography analysis and screening of bioactive fraction}

The thin-layer chromatography analysis explained by Viju et al. (2019) was used for the isolation of the bioactive fractions present in the crude extracts of symbiotic bacteria. A drop of extracts (ESB) was run through the stationary phase prepared with silica gel $G$ with the aid of the mobile phase prepared by mixing methanol $(2 \%)$, ethyl acetate $(3 \%)$ and chloroform $(5 \%)$. Subsequently, the fractions embedded in the silica gel were visualized by iodine and scraped off and mixed with 
methanol for $14 \mathrm{~min}$. This mixture was then centrifuged and a fraction (liquid phase) was separated. The fractions were then evaporated and tested for bioactivity using antimicrobial susceptibility test described earlier in the antibacterial assay.

\section{GC-MS analysis}

The organic compounds present in the bioactive fractions isolated from the extract of symbiotic bacteria ( $B$. firmus, B. cereus and B. subtilis) were analysed in gas chromatography (GC Clarus 500 Perkin Elmer) assembled with a capillary column. The temperature of the injection port was maintained at $250^{\circ} \mathrm{C}$, and the sample was injected to the column using the mobile phase helium at $1 \mathrm{ml} / \mathrm{min}$ flow rate. The column oven temperature was started off at $110{ }^{\circ} \mathrm{C}$ for $2 \mathrm{~min}$ and then turned up gradually by programming at $10{ }^{\circ} \mathrm{C} / \mathrm{min}$ and ended up at $280{ }^{\circ} \mathrm{C} / 9 \mathrm{~min}$ (an isothermal process). Subsequently, the mass spectral data were taken and compared with the mass spectral data available in the NIST library (Casuga et al. 2016).

\section{Data analysis}

Student's $T$ test was performed to analyse the biofilm inhibition of the extracts of symbiotic bacteria against Alteromonas sp. in different assays. The variation in the production of EPS (carbohydrate and protein) between control and ESB-treated biofilm-forming bacterium was analysed by one-way ANOVA. These statistical analyses were carried out using MS Excel 7 program.

\section{Results}

\section{Bacterial symbionts of marine gastropods}

The number of bacterial symbionts of gastropods isolated during this study was 65 . Among them, 22 bacteria were the symbionts of gastropods which were collected from the Thengapattanam coast, followed by 29 bacteria that were the symbionts of the gastropods collected from the Colachel coast and 14 bacteria that were the symbionts of the gastropods collected from the Kanyakumari coast.

\section{Antagonistic effect of bacterial symbionts of gastropods}

Twenty-eight bacterial symbionts of gastropods were found to produce the compounds with bioactive potential against Alteromonas sp., and the zone of inhibition observed was lying between 1 and $2.5 \mathrm{~mm}$. Based on the inhibition zone (antagonistic activity) that appeared around the bacterial colony, 15 broad active strains (TPM7, TPM9, TPM10, TPM13, TPM21, CAL9, CAL10, CAL11, CAL16, CAL20, KKI3, KKI4, KKI8, KKI11 and KKI12) were selected for further studies (Table 1). The tentative characterization (based on biochemical characters) result of these 15 bacterial strains revealed that 5 of them were belonging to the genus
Pseudomonas and 4 strains were belonging to Bacillus. Also, 3 strains from the genus Alteromonas and 2 strains from Flavobacterium were recorded. The remaining 1 strain was belonging to the genus Aeromonas (Table 2).

\section{Antibacterial activity of ESB}

The result of antibacterial assay revealed that 9 out of 15 extracts of symbiotic bacteria showed inhibitory activity against Alteromonas sp. (biofilm bacterium) and the observed zones of inhibition were between 7 and $13 \mathrm{~mm}$. Among them, the extract of three bacteria TPM7, CAL9 and KKI12 overpowered the others and the observed zone of inhibition was $13 \pm 1,12.33 \pm 1.15$ and $11 \pm 0.0$ $\mathrm{mm}$ respectively (Table 3 ).

\section{Identification of bioactive bacteria}

The 16S rRNA bacterial identification revealed that all the three potent bacteria (TPM7, CAL9 and KKI12) were belonging to the genus Bacillus and the constructed phylogenetic tree is given in Fig. 1. The bacterium TPM7 showed 99\% similarity with the nucleotides of Bacillus firmus available in the NCBI GenBank. Similarly, the bacterium CAL9 showed 98\% similarity with Bacillus cereus and the bacterium KKI12 showed 99\% similarity with Bacillus subtilis in the phylogenetic analysis. The 16S rRNA sequences of all the three bacterial strains (B. firmus-KX669624; B. cereus-KX669625; and B. subtilis-KX685340) were submitted to GenBank (NCBI).

\section{Antibiofilm effect of ESB on hydrophobic surface}

The microtiter assay revealed the antibiofilm potential of the extracts of symbiotic bacteria against Alteromonas sp. The observed OD value of the biofilm developed by Alteromonas sp. on the control (without any treatment) microtiter plate well was $0.341 \pm 0.01$, whereas this biofilm development (OD value) was significantly decreased to $0.224 \pm 0.02(P<0.004), 0.253 \pm 0.01(P<0.012)$ and $0.244 \pm 0.025(P<0.004)$ in the wells treated with the extracts isolated from the bacteria $B$. firmus, $B$. cereus and B. subtilis respectively (Fig. 2).

\section{Antibiofilm effect of ESB on hydrophilic surface}

The extracts of symbiotic bacteria displayed strong biofilm inhibition, and the variation in biofilm formation between control and bacterial extract-treated tubes can be seen in Fig. 3. The tube which contained control Alteromonas sp. showed the biofilm formation of 0.320 \pm 0.01 , and this was significantly reduced to $0.237 \pm$ $0.012(P<0.009), 0.238 \pm 0.032(P<0.04)$ and $0.255 \pm$ $0.018(P<0.02)$ when the test tubes were treated with the extracts of the symbiotic bacterium $B$. firmus, $B$. cereus and B. subtilis respectively. 
Table 1 Antagonistic activity of bacterial symbionts of molluscans collected from Kanyakumari coastal waters

\begin{tabular}{llll}
\hline S. no & Name of the source (gastropods) & Name (code) of the strains & Zone of inhibition (mm) \\
\hline 1 & Murex sp. & TPM7 & 2 \\
2 & Murex sp. & TPM9 & 2.5 \\
3 & Murex sp. & TPM10 & 1 \\
4 & Babylonia sp. & TPM13 & 2.5 \\
5 & Pinctada sp. & TPM21 & 2 \\
6 & Turritella sp. & CAL9 & 2.5 \\
7 & Turritella sp. & CAL10 & 1 \\
8 & Perna sp. & CAL11 & 1.5 \\
9 & Pinctada sp. & CAL16 & 2.5 \\
10 & Sepia sp. & CAL20 & 2 \\
11 & Busycon sp. & KKI3 & 2.5 \\
12 & Busycon sp. & KKI4 & 2.5 \\
13 & Turbo sp. & KKI8 & 2 \\
14 & Conus sp. & KKI11 & 2.5 \\
15 & Conus sp. & KKI12 & 2.5
\end{tabular}

\section{Influence of ESB on the synthesis of EPS by biofilm} bacterium

The extract treatment significantly inhibited the EPS (carbohydrate and protein) synthesis by biofilm bacterium Alteromonas sp. The carbohydrate content $(0.352$ $\pm 0.02 \mathrm{mg} / \mathrm{g}$ ) of EPS synthesized by Alteromonas sp. grown without any treatment was significantly (oneway ANOVA: $F=22.12, P<0.0003)$ reduced to $0.246 \pm$ $0.02,0.231 \pm 0.01$ and $0.224 \pm 0.02 \mathrm{mg} / \mathrm{g}$ on the bacterial culture treated with the extracts of B. firmus, $B$. cereus and $B$. subtilis respectively (Fig. 4a). Likewise, the protein content $(0.282 \pm 0.01 \mathrm{mg} / \mathrm{g})$ of EPS synthesized

Table 2 Characterization of bacterial strains using the data obtained from biochemical and morphological analysis

\begin{tabular}{|c|c|c|c|c|c|c|c|c|c|c|c|c|c|c|c|c|c|}
\hline \multirow[t]{2}{*}{ S. no } & \multirow{2}{*}{\multicolumn{2}{|c|}{$\begin{array}{l}\text { Biochemical and } \\
\text { physiological test }\end{array}$}} & \multicolumn{15}{|c|}{ Symbiotic bacterial strains } \\
\hline & & & TPM7 & TPM 9 & TPM10 & TPM13 & TPM21 & CAL9 & CAL10 & CAL11 & CAL16 & CAL20 & KKI3 & KKI4 & KKI8 & KKI11 & KKI12 \\
\hline 1 & \multicolumn{2}{|c|}{ Gram staining } & + & - & - & - & - & + & - & + & - & - & - & - & - & - & + \\
\hline 2 & \multicolumn{2}{|c|}{ Morphology } & Rod & Rod & Rod & Rod & Rod & Rod & Rod & Rod & Rod & Rod & Rod & Rod & Rod & Rod & Rod \\
\hline 3 & \multicolumn{2}{|c|}{ Motility } & - & + & + & + & + & - & + & - & + & + & - & + & + & - & - \\
\hline 4 & \multicolumn{2}{|c|}{ Indole production } & + & - & + & - & - & + & - & + & - & + & - & - & + & - & + \\
\hline 5 & \multicolumn{2}{|c|}{ Methyl red } & - & + & - & + & + & - & + & - & + & + & - & + & - & - & - \\
\hline 6 & \multicolumn{2}{|c|}{ Voges-Proskauer } & - & - & - & - & - & - & - & - & - & + & - & - & - & - & - \\
\hline 7 & \multicolumn{2}{|c|}{ Citrate utilization } & + & - & + & - & - & + & - & + & - & + & + & - & + & + & + \\
\hline 8 & \multicolumn{2}{|c|}{ Starch hydrolysis } & + & + & - & + & + & + & + & + & + & + & - & + & - & - & + \\
\hline 9 & \multicolumn{2}{|c|}{ Urea hydrolysis } & + & - & - & - & - & + & - & + & + & - & + & - & - & + & + \\
\hline \multirow[t]{4}{*}{10} & \multirow[t]{4}{*}{ TSI } & Alkaline & + & + & - & + & + & + & + & + & - & + & + & - & + & + & + \\
\hline & & Acid & + & - & - & + & + & - & + & + & - & - & + & + & - & + & + \\
\hline & & Gas & - & - & - & - & - & - & - & - & - & - & - & - & - & - & - \\
\hline & & $\mathrm{H}_{2} \mathrm{~S}$ & - & - & - & - & - & - & - & - & - & + & - & - & - & - & - \\
\hline 11 & \multicolumn{2}{|c|}{ Catalase } & + & + & + & - & - & + & + & + & - & + & + & + & + & + & + \\
\hline 12 & \multicolumn{2}{|c|}{ Oxidase } & - & - & + & + & + & - & - & - & + & + & + & - & + & + & - \\
\hline 13 & \multicolumn{2}{|c|}{ Nitrate reduction } & + & - & + & + & + & + & - & + & + & + & + & - & + & + & + \\
\hline 14 & \multicolumn{2}{|c|}{ Casein hydrolysis } & - & - & - & - & - & - & - & - & - & + & + & - & - & + & - \\
\hline 15 & \multicolumn{2}{|c|}{ Gelatin hydrolysis } & - & + & - & - & - & - & - & - & - & - & + & + & - & + & - \\
\hline 16 & \multicolumn{2}{|c|}{ BMDB } & Bac. & Pse. & Pse. & Alt. & Alt. & Bac. & Pse. & Bac. & Alt. & Aer. & Fla. & Pse. & Pse. & Fla. & Bac. \\
\hline
\end{tabular}


Table 3 Antibacterial activity of bacterial extracts isolated from the gastropod-associated bacteria

\begin{tabular}{lll}
\hline S. no & Symbiotic bacteria & $\begin{array}{l}\text { Zone of inhibition (mm) } \\
\text { against Alteromonas sp. }\end{array}$ \\
\hline 1 & TPM7 (Bacillus sp.) & $13 \pm 1.0$ \\
2 & TPM9 (Pseudomonas sp.) & - \\
3 & TPM10 (Pseudomonas sp.) & $11.66 \pm 1.15$ \\
4 & TPM13 (Alteromonas sp.) & $8.66 \pm 0.57$ \\
5 & TPM21 (Alteromonas sp.) & - \\
6 & CAL9 (Bacillus sp.) & $12.33 \pm 1.1$ \\
7 & CAL10 (Pseudomonas sp.) & - \\
8 & CAL11 (Bacillus sp.) & - \\
9 & CAL16 (Alteromonas sp.) & - \\
10 & CAL20 (Aeromonas sp.) & $11.66 \pm 0.57$ \\
11 & KKI3(Flavobacterium sp.) & $11.33 \pm 1.15$ \\
12 & KKI4 (Pseudomonas sp.) & $11 \pm 0.0$ \\
13 & KKI8 (Pseudomonas sp.) & $9 \pm 1.0$ \\
14 & KKI11 (Flavobacterium sp.) & - \\
15 & KKI12 (Bacillus sp.) & $12.66 \pm 0.5$ \\
\hline
\end{tabular}

by the control Alteromonas sp. was significantly (oneway ANOVA: $F=4.98, P<0.03)$ reduced to $0.199 \pm$ $0.04,0.182 \pm 0.02$ and $0.181 \pm 0.05 \mathrm{mg} / \mathrm{g}$ when the culture was treated with the extracts of $B$. firmus, $B$. cereus and B. subtilis respectively (Fig. 4b).

\section{Chromatography analysis and screening of bioactive fractions}

The TLC chromatogram of the extract of $B$. firmus developed three (1,2 and 3 ) distinct fractions on the thin-layer chromatogram. Of the three, fraction 3 was found to possess bioactive molecules (Fig. 5a and Table 4). Similarly, the TLC chromatogram of the extract of the bacterium $B$. cereus displayed three (1,2 and 3$)$ distinct spots and fraction 2 was identified as the bioactive fraction (Fig. $5 \mathrm{~b}$ and Table 4). Whereas the extract produced by the bacterium B. subtilis developed only two fractions on the thin-layer chromatogram, fraction 2 was found to possess antibiofilm agents (Fig. 5c).

\section{GC-MS analysis}

GC-MS chromatogram of the fraction of $B$. firmus that exhibited an antibiofilm activity showed the presence of compounds like 2-ethylacridine, indolizine and anthranilic acid (Fig. 6a and Table 5), whereas components such as 3-methoxypropionic acid, 3-(dimethylamino) propanamide, phenyltoloxamine, cis-3-octadecenoic acid, octadecenoic acid, N-allyl-N,N-dimethylamine and 3 -piperidinol were detected in the fraction of B. cereus that displayed bioactivity (Fig. 6b and Table 5). Likewise, components such as 2-acetylbenzoic acid, trans-1chloropropene, methional, isobutane, 1-buten-3-yne and orthosilicic acid were found in the fraction of B. subtilis which showed an antibiofilm activity (Fig. 6c and Table 5).

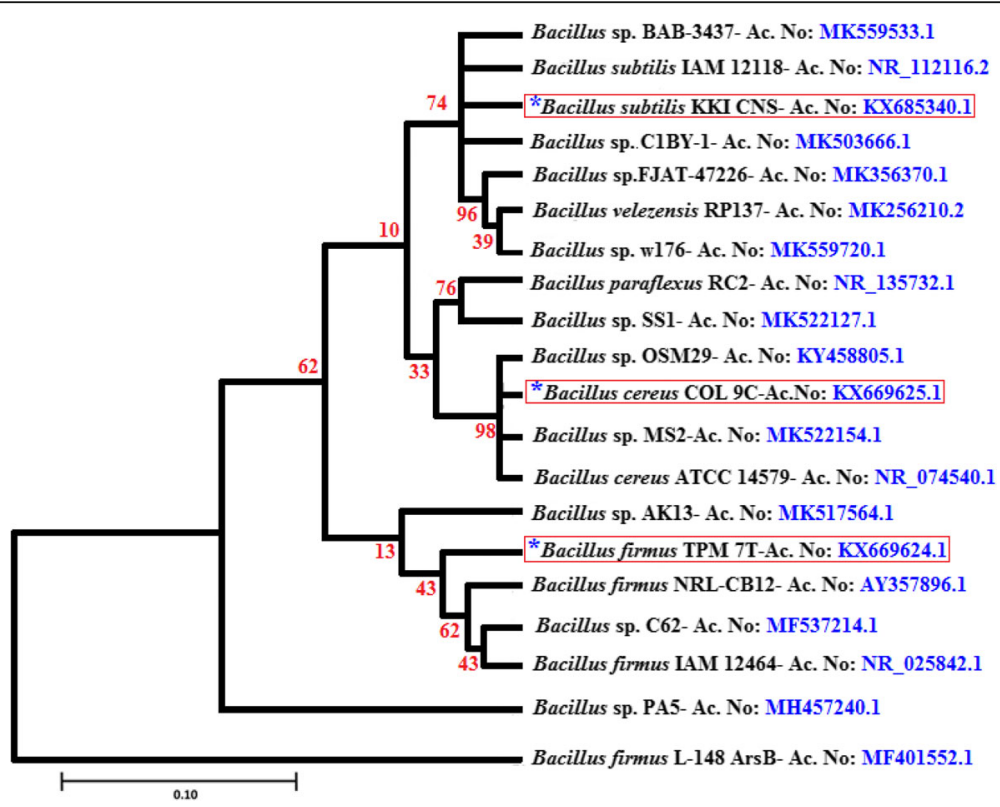

Fig. 1 The phylogenetic analysis of symbiotic bacteria Bacillus sp. The sequence of three symbiotic bacteria (indicated in the figure with an asterisk) was aligned together with 17 bacterial sequences obtained from NCBI. The phylogenetic tree was constructed based on the neighbourjoining method using MEGA7 software 


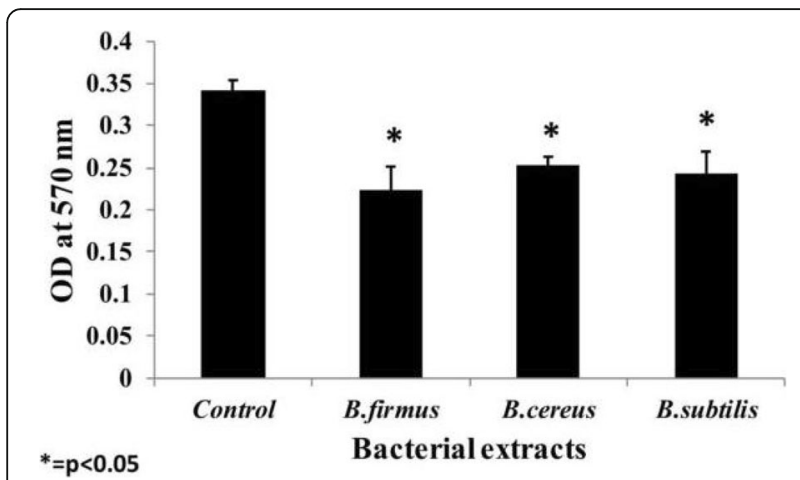

Fig. 2 Antibiofilm activity of bacterial extracts on hydrophobic surface (microtiter plate method). The image shows the difference in the biofilm formed by Alteromonas sp. on control and bacterial extract-treated wells

\section{Discussion}

Biofilm formation on a substrate is initiated by microbial adhesion, and the rate of adhesion significantly varies based on the characteristics of the surfaces (Gomes and Mergulhao, 2017). Typically, the rate of microbial adhesion on hydrophobic (plastic-microtiter plate) surfaces is higher than that on hydrophilic (glass test tube) surfaces (Bendinger et al., 1993). Therefore, in this study, the antibiofilm effect of the extracts of symbiotic bacteria

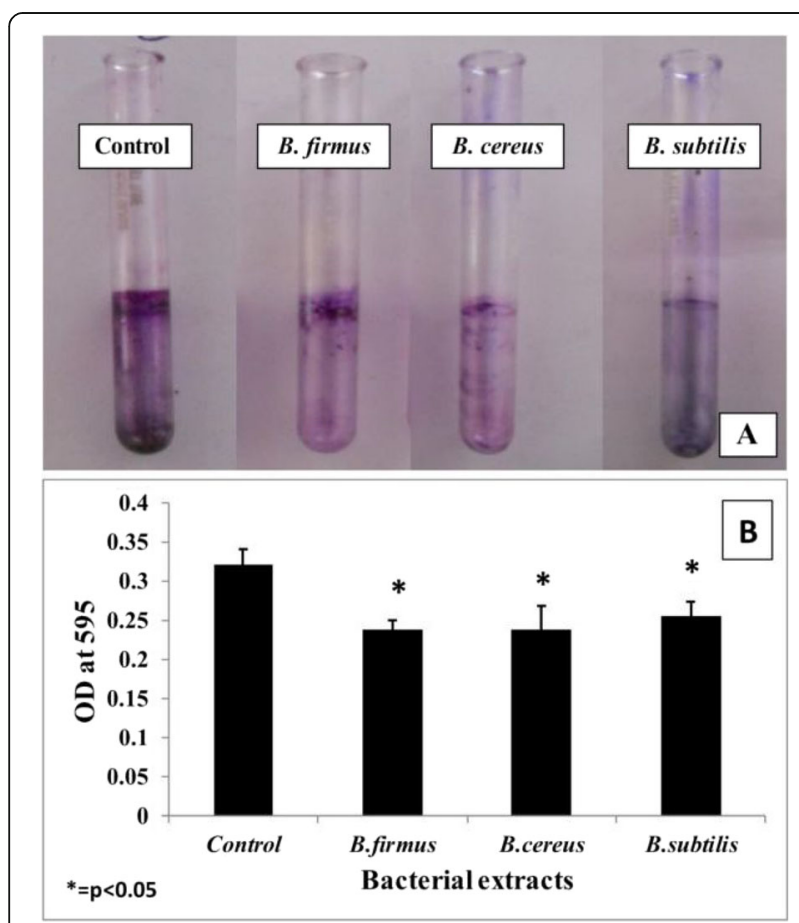

Fig. 3 Antibiofilm activity of bacterial extracts on hydrophilic surface (test tube method). a Bacterial biofilm developed on control and bacterial extract-treated test tubes. $\mathbf{b}$ Plot showing the variation in the biofilm developed on control and bacterial extract-treated test tubes

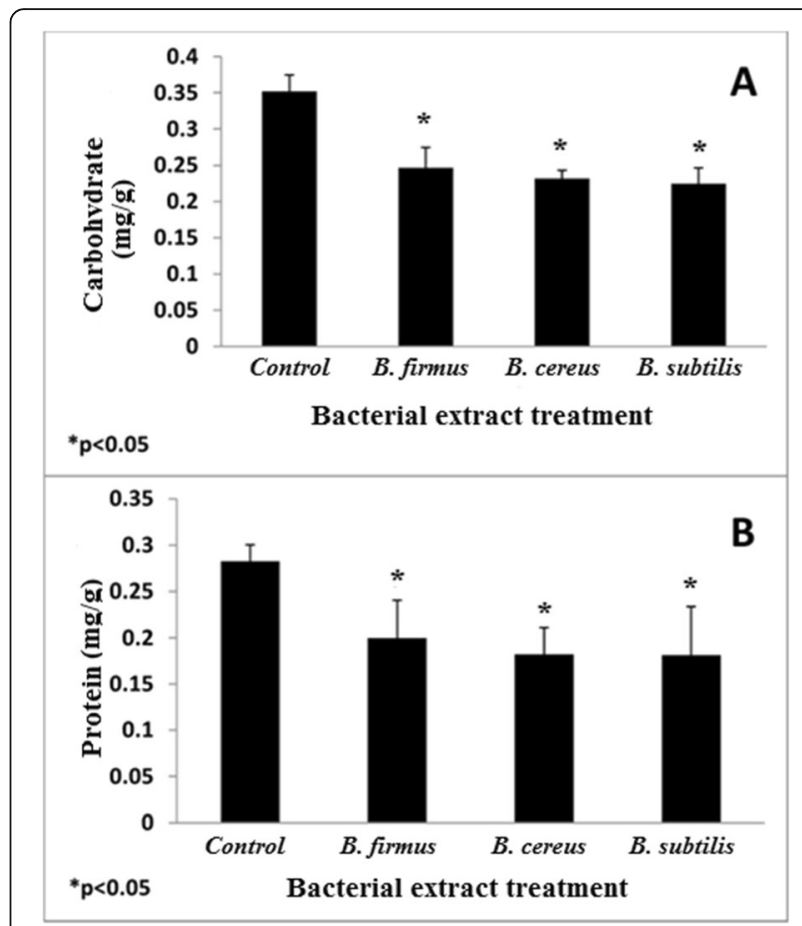

Fig. 4 Influence of bacterial extracts on the production of EPS in biofilm-forming bacterium Alteromonas sp. a Carbohydrate concentration of EPS produced by the control and extract-treated biofilm-forming bacterium Alteromonas sp. b Protein concentration of EPS produced by the control and extract-treated bacterium Alteromonas sp. The symbol asterisk above the bars indicates the difference between control and treatments which was analysed by Dunnett multiple comparison test

was tested on both hydrophobic and hydrophilic surfaces. The result revealed that the bacterial extracts significantly reduced the biofilm formation on both hydrophobic and hydrophilic surfaces. There are similar studies that used hydrophobic and hydrophilic surfaces to evaluate the antibiofilm effect of natural products. For instance, Karwacki et al. (2013) analysed the antibiofilm effect of bacterial extracts using a microtiter plate (hydrophobic surface) and found 5 out of 12 bacterial extracts considerably reduced the biofilm formation of $S$. aureus, whereas Mathur et al. (2013) reported the antibiofilm activity of the plant oils isolated from garlic, neem, clove, eucalyptus and tulsi in hydrophilic (glass) surface. However, the extracts of symbiotic bacteria $(B$. firmus, B. cereus and B. subtilis) significantly inhibited the attachment of biofilm-forming bacteria on both hydrophobic and hydrophilic surfaces.

It has been reported that bioactive compounds obtained from living organisms could prevent the microbial adhesion by repulsive action (Kelly et al., 2003). Further antibiofilm mechanisms such as inhibition of quorum sensing pathway, inhibition of regulated stringent response, inhibition of cell division, dispersion of extracellular polymeric 


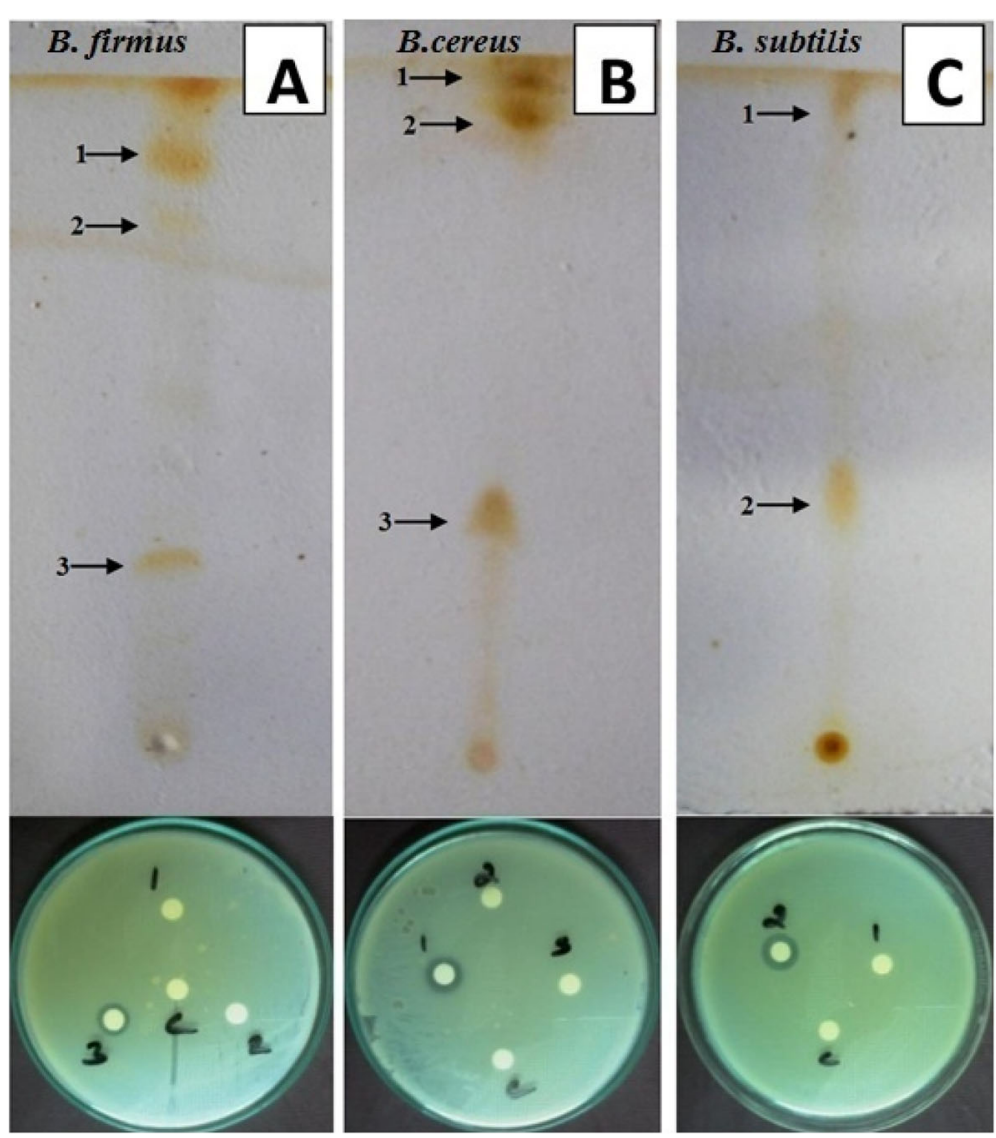

Fig. 5 Isolation of bioactive fractions from the bacterial crude extract. a Thin-layer chromatogram and the bioactivity of the fractions isolated from B. firmus. $\mathbf{b}$ Thin-layer chromatogram and the bioactivity of the fractions isolated from B. cereus. $\mathbf{c}$ Thin-layer chromatogram and the bioactivity of the fractions isolated from B. subtilis

substances, disaggregation of LPS, inhibition of macromolecule synthesis and inhibition of curli biosynthesis have also been reported (Park et al., 2011; Fuente-Nunez et al., 2014; Roy et al., 2018). For instance, Hentzer et al. (2002) reported the QS mode of the antibiofilm activity of the halogenated furanones isolated from the seaweed Delisea pulchra. Contrarily, some authors have revealed the biofilm dispersal mode of antibiofilm effect of natural products (Rendueles et al., 2013; Karwacki et al., 2013).

Notably, in the current study, the extracts of symbiotic bacteria (B. firmus, B. cereus and B. subtilis) substantially reduced the EPS production in biofilm-forming bacterium Alteromonas sp. The reduction in the EPS production would certainly inhibit the biofilm formation, due

Table 4 Rf values of the TLC obtained fractions isolated from the symbiotic bacterial extracts and their bioactivity

\begin{tabular}{lllll}
\hline S. no & Bacterial extracts & TLC obtained Fractions & Rf value $(\mathrm{cm})$ & Bioactivity $(\mathrm{mm})$ \\
\hline 1. & B. firmus (TPM7) & Fraction 1 & 0.89 & - \\
& & Fraction 2 & 0.79 & - \\
2. & B. cereus (CAL9) & Fraction 3 & 0.25 & - \\
& & Fraction 1 & 0.88 & - \\
& & Fraction 2 & 0.84 & 8 \\
3. & Fraction 3 & 0.35 & - \\
& & Fraction 1 & 0.94 & 12 \\
\hline
\end{tabular}




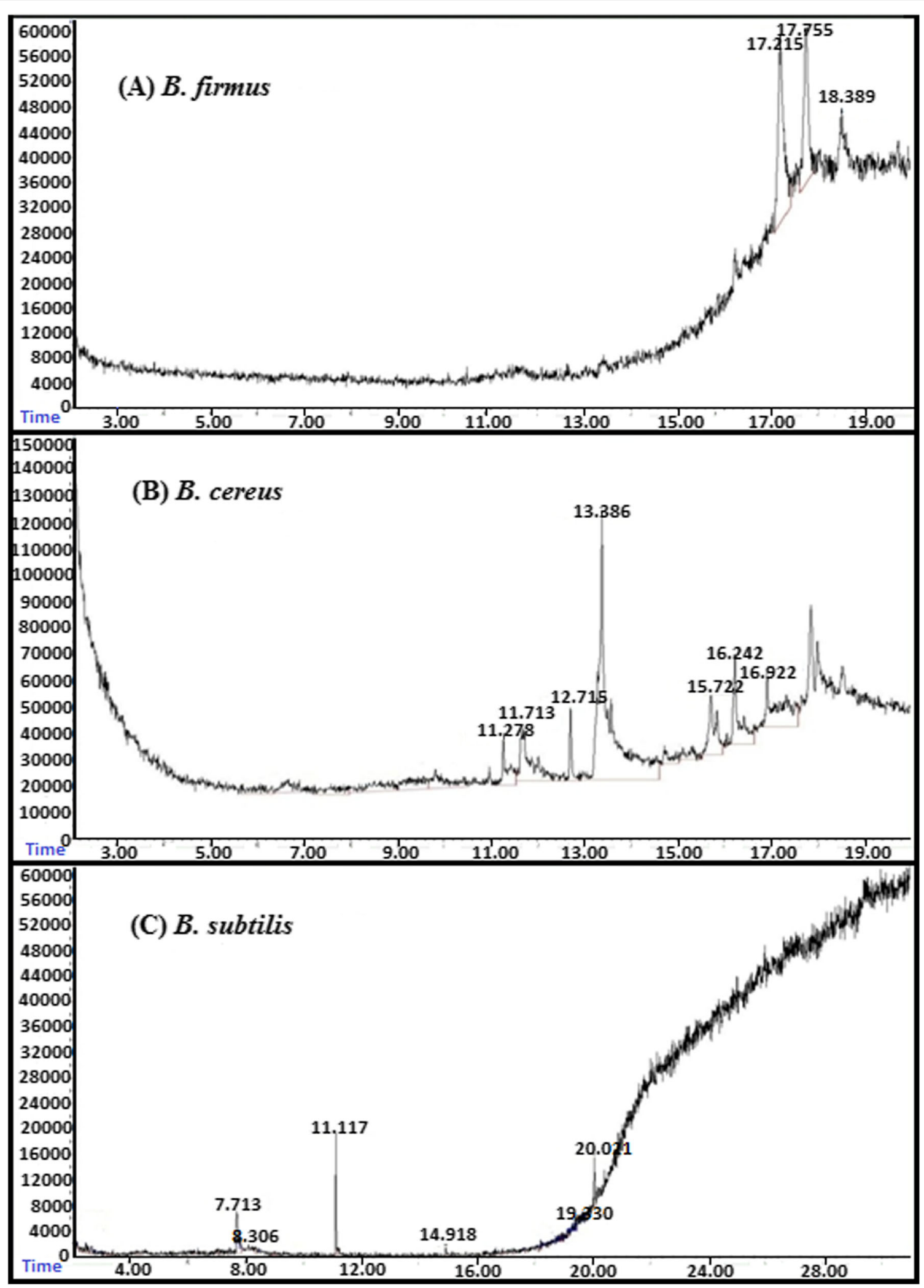

Fig. 6 GC-MS spectrum of the bioactive fractions. a Fraction isolated from the extract of the symbiotic bacterium $B$. firmus. $\mathbf{b}$ Fraction isolated from the extract of the symbiotic bacterium B. cereus. c Fraction isolated from the extract of the symbiotic bacterium B. subtilis 
Table 5 Compounds present in the bioactive fractions isolated from the symbiotic bacteria B. firmus, B. cereus and B. subtilis

\begin{tabular}{llll}
\hline S. no & Retention time $(\mathrm{min})$ & Name of the compound & Bacterial source \\
\hline 1 & 17.215 & 2-Ethylacridine & B. firmus \\
2 & 17.755 & Indolizine & B. firmus \\
3 & 18.389 & Anthranilic acid & B. firmus \\
4 & 11.278 & 3-Methoxypropionic acid & B. cereus \\
5 & 11.713 & 3-(Dimethylamino)propanamide & B. cereus \\
6 & 12.715 & Phenyltoloxamine & B. cereus \\
7 & 13.386 & Cis-3-Octadecenoic acid & B. cereus \\
8 & 15.722 & Octadecenoic acid & B. cereus \\
9 & 16.242 & N-Allyl-N,N-dimethylamine & B. cereus \\
10 & 16.922 & 3-Piperidinol & B. cereus \\
11 & 7.713 & Trans-1-Chloropropene & B. subtilis \\
12 & 8.306 & Methional & B. subtilis \\
13 & 11.117 & 2-Acetylbenzoic acid & B. subtilis \\
14 & 14.918 & Isobutane & B. subtilis \\
16 & 19.330 & 1-Buten-3-yne & B. subtilis \\
\hline
\end{tabular}

to the fact that the polymer component of EPS forms a highly hydrated matrix that keeps the cells together and strongly interacts with the substratum (Pal and Paul, 2013). Furthermore, it has been reported that bacterial strains which are not in a position to produce EPS are not able to form biofilm on the surfaces (Watnick and Kolter, 1999). Supportively, Olofsson et al. (2003) evidenced the biofilm inhibition of N-acetyl-L-cysteine (NAC) against some bacteria (Acinetobacter, Klebsiella, Pseudomonas and Bacillus) which were not able to produce EPS due to the bacteriostatic effect of NAC. Some similar studies have also reported the antibiofilm effect of NAC against the bacteria Staphylococcus, Streptococcus, Haemophilus and Moraxella species (Zheng et al., 1999). NAC is an antibacterial agent with bacteriostatic mode of action and used in some medical treatments (Riise et al., 2000). According to the previous reports and the result of the present study, it is believed that the antibiofilm effect of the extracts produced by Bacillus sp. might be bacteriostatic mode of action. The bacteriostatic mode of biofilm inhibition by the compounds isolated from the natural sources has been documented (Trentin et al., 2013).

Generally, the synthesis of bioactive compounds by the bacteria Bacillus species has frequently been documented; some of the reported species are B. amyloliquefaciens, B. cereus, B. laterosporus, B. licheniformis, $B$. silvestris and B. subtilis (Mondol et al., 2013; Santhi et al., 2017). These compounds (polyketides, peptides and fatty acids) have shown antimicrobial, antifungal, antibiofilm, antifouling, anticancer, antialgal and bioinsecticidal activities (Baruzzi et al., 2011; Hamdache et al., 2011; Ben Khedher et al., 2011). Notably, the antibiofilm effect of bacteria belonging to Bacillus sp. isolated from the marine environment has been reported extensively (Sayem et al., 2011; Satheesh et al., 2012). For instance, in an investigation, Coasta et al. (2018) isolated a bacterium Bacillus sp. P34 responsible for the synthesis of the peptide P34 that displayed a strong antibiofilm activity against Staphylococcus sp.

In the current study, the compounds present in the bioactive fractions isolated from the symbiotic Bacillus sp. were belonging to aromatic acids, fatty acids and carboxylic acids. The production of some of these compounds by the bacteria has already been documented (Gad et al., 2016; Zhang et al., 2017). Wagner-Dobler et al. (2002) isolated an antibacterial anthranilic acid (yellow tryptanthrin) from the North Sea bacterium (Flexibacteria). Sharad et al. (2016) reported the production of two fatty acid derivatives such as octadecenoic acid and cis-3-octadecenoic acid by the marine bacterium Alcaligenes faecalis that displayed an antibiofilm activity. Besides bacteria, the bioactive fractions of fungi, plants and animals have been reported to possess some of the compounds that were detected in the bioactive fraction of symbiotic bacteria Bacillus sp. Teponno et al. (2017) reported the production of anthranilic acid derivatives that displayed antibacterial activity by the fungus Dendrothyrium variisporum. The presence of the compound 2-acetylbenzoic acid was found in the bioactive extract obtained from the sea cucumber Halothuria atra (Dhinakaran and Lipton, 2014), while Foo et al. (2015) found the presence of 2-ethylacridine in the fraction of Piper betle leaves that displayed antimicrobial activity. 
However, the antibiofilm mode of action of the compounds produced by the symbiotic bacteria (B. firmus, $B$. cereus and B. subtilis) is unknown. Further purification and spectroscopy analysis like nuclear magnetic resonance (NMR) could reveal the responsible antibiofilm agents produced by the symbiotic bacteria Bacillus sp.

Hundreds of compounds with antibiofilm properties have been isolated, identified and documented from natural sources such as plants, animals and microbes. The compounds isolated from the natural sources can be applied in the environment in the form of antibiofilm coatings. For the development of antibiofilm coatings, a particular amount of compound is required that can be obtained from renewable resources like microbes. The marine environment has vast number of microorganisms, and these microbes could produce high amount of biologically significant metabolites, especially those that are associated with marine macroorganisms. Therefore, these novel symbiotic microbes could be used as the resources for the production of antibiofilm compounds.

\section{Acknowledgements}

The authors thank the Manonmaniam Sundaranar University for providing the facilities required to conduct the research. Also, we are grateful to UGC for the financial assistance.

\section{Authors' contributions}

SS and SMJP designed the study. NV performed the experiments. SS and SMJP analysed the data. NV and SS wrote the paper. All authors read and approved the final manuscript.

\section{Funding}

This research work was supported by UGC-New Delhi, India, under the project scheme Ref. F. No. 39-294/2010 SR.

\section{Competing interests}

The authors declare that they have no competing interests.

\section{Author details}

${ }^{1}$ CMST, M.S. University, Tirunelveli, Tamilnadu, India. ${ }^{2}$ Department of Marine Biology, King Abdulaziz University, Jeddah, Saudi Arabia.

Received: 16 September 2019 Accepted: 29 January 2020

Published online: 03 March 2020

\section{References}

Anand TP, Bhata AW, Shouche YS, Siddharth URY, Sarmaa SP (2006) Antimicrobial activity of marine bacteria associated with sponges from the waters off the coast of South East India. Microbiol Res 161:252-262

Baruzzi F, Quintieri L, Morea M, Caputo L (2011) Antimicrobial compounds produced by Bacillus sp. and applications in food science against microbial pathogens. Communicat Curr Res Technol Advan 2:1102-1111

Ben Khedher S, Kamoun A, Aaoua S, Zouari N (2011) Improvement of Bacillus thuringiensis bioinsecticide production by sporeless and sporulating strains using response surface methodology. N Biotechnol 28(6):705-712

Bendinger B, Rijnaarts HHM, Altendorf K, Zehnder AJB (1993) Physicochemical cell surface and adhesive properties of coryneform bacteria related to the presence and chain length of mycolic acids. App environ microbiol 59:3973-3977

Camesi ABR, Alukito A, Waturangi DE, Kwan HJ (2016) Screening of antibiofilm activity from marine bacteria against pathogenic bacteria. Microbiol indones 10(3):87-94

Campoccia D, Montanaro L, Arciola CR (2006) The significance of infection related to orthopedic devices and issues of antibiotic resistance. Biomaterials 27:2331-2339
Cao S, Wang J, Chen H, Chen D (2011) Progress of marine biofouling and antifouling technologies. Chin Sci bull 56:598-612

Casuga FP, Castillo AL (2016) Corpuz MJT (2016) GC-MS analysis of bioactive compounds present in different extracts of an endemic plant Broussonetia luzonica (Blanco) (Moraceae) leaves. Asian Pac J Trop Biomed 6(11):957-961

Chen J, Rossman ML, Pawar DM (2007) Attachment of enterohemorragic Escherichia coli to the surface of beef and a culture medium. LWT - Food Sci Technol 40:249-254

Coasta GA, Rossatto FCP, Medeiros AW, Correa APF, Brandelli A, Frazzon APG, Motta ADS (2018) Evaluation antimicrobial and antibiofilm activity of the antimicrobial peptide P34 against Staphylococcus aureus and Enterococcus faecalis. An Bras Acad Sci. 90(1):73-84

Dhinakaran DI, Lipton AP (2014) Bioactive compounds from Holothuria atra of Indian ocean. Springer Plus 3:673

Donlan RM (2009) Preventing biofilms of clinically relevant organisms using bacteriophage. Trends Microbiol 17:66-72

Dubois M, Gills KA, Hamilton JK, Rebers PA, Smith F (1956) Colorimetric method for determination of sugar and related substances. Anal Chem 28:350-356

Foo LW, Selleh E, Mamat SNH (2015) Extraction and qualitative analysis of Piper Betle leaves for antimicrobial activities. Int J Engin Technol Sci Res 2:1-8

Francolini I, Donelli G (2010) Prevention and control of biofilm-based medicaldevice-related infections. FEMS Immunol. Med Microbiol 59:227-238

Fuente-Nunez CDL, Reffuveille F, Haney EF, Straus SK, Hancock RE (2014) Broadspectrum anti-biofilm peptide that targets a cellular stress response. PLoS Pathog 22 10(5):e1004152

Gad AM, Beltagy EA, Abdul-Raouf UA, El-Shenawy MA, Abouelkheir SS (2016) Screening of marine fatty acids producing bacteria with antimicrobial capabilities. Chem Adv Mater 1(2):41-54

Ghaima KK, Rasheed SF, Ahmed EF (2013) Antibiofilm, antibacterial and antioxidant activities of water extract of Calendula officinalis flowers. Int J Biol Pharma Res 4(7):465-470

Gomes LC, Mergulhao FJ (2017). SEM analysis of surface impact on biofilm antibiotic treatment. Scanning ID 2960194: 7.

Hamdache A, Azarken R, Lamarti A, Aleu J, Collado IG (2011) Non-peptide metabolites from the genus Bacillus. J Nat Prod. 74(4):893-899

Hentzer M, Riedel K, Rasmussen TB, Heydorn A, Andersen JB, Parsek MR, Rice SA, Eberl L, Molin S, Hoiby N, Kijelleberg S, Givskov M (2002) Inhibition of quorum sensing in Pseudomonas aeruginosa biofilm bacteria by a halogenated furanone compound. Microbiology 148:87-102

Hoiby N, Ciofu O, Johansen HK, Song ZJ, Moser C, Jensen PO (2011) The clinical impact of bacterial biofilms. Int J Oral Sci 3:55-65

Jiang P, Li J, Han F, Duan G, Lu X, Gu Y, Yu W (2011) Antibiofilm activity of an exopolysaccharide from marine bacterium Vibrio sp. QY101. PLOSONE 6(4): e18514.

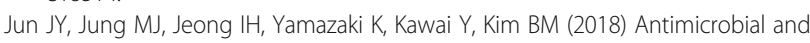
antibiofilm activities of sulfated polysaccharides from marine algae against dental plaque bacteria. Mar drugs 16(9):E301

Karwacki MT, Kadouri DE, Bendaoud M, Izano EA, Sampathkumar V, Inzana TJ, Kaplan JB (2013) Antibiofilm activity of Actinobacillus pleuropneumoniae serotype 5 capsular polysaccharide. PLoS ONE 8(5):e63844

Kelly S, Jensen PR, Henkell TP, Fenical W, Pawlik JR (2003) Effects of Caribbean sponge extracts on bacterial attachment. Aquat Microb Ecol 31:175-182

Khelissa SO, Abdallah M, Jama C, Faille C, Chihib NE (2017) Bacterial contamination and biofilm formation on abiotic surfaces and strategies to overcome their persistence. J Mate Environ Sci. 8(9):3326-3346

Koch G, Verney J, Thompson N, Moghissi O, Gould M, Payer J (2016) International measures of prevention, application and economics of corrosion technologies study. NACE International Impact.

Kumar S, Stecher G, Tamura K (2016) MEGA 7: Molecular evolutionary genetics analysis version 7.0 for bigger datasets. Mol Biol Evol. 33:1870-1874

Little BJ, Lee JS, Ray RI (2008) The influence of marine biofilms on corrosion: a concise review. Electrochim Acta 54:2-7

Lopez D, Vlamakis H, Kolter R (2010) Biofilms. Cold Spring Harbor perspectives in biology. 2:1-11

Lowry OH, Rosebrough NJ, Far AL, Randall RJ (1951) Protein measurement with the folin-phenol reagent. J Biol Chem 193:265-275

Mathur S, Udgire M, Khambhapati A (2013) Effect of essential oils on biofilm formation by Proteus mirabilis. Int J Pharm Bio Sci B 4(4):1282-1289

Mondol MAM, Shin HJ, Islam MT (2013) Diversity of secondary metabolites from marine Bacillus species: chemistry and biological activity. Mar Drugs 11:2846-2872 
Olofsson AC, Hermansson M, Elwing H (2003) N-Acetyl-L-cysteine affects growth, extracellular polysaccharide production and bacterial biofilm formation on solid surfaces. App Environ Microbial 69:4814-4822

Pal A, Paul AK (2013) Optimization of cultural conditions for production of extracellular polymeric substances (EPS) by Serpentine Rhizobacterium Cupriavidus pauculus KPS 201. J Polym. ID 692374:1-7

Park SC, Park Y, Hahm KS (2011) The role of antimicrobial peptides in preventing multidrug-resistant bacterial infections and biofilm formation. Int J Mol Sci 12:5971-5992

Rendueles O, Kapla JB, Ghigo JM (2013) Antibiofilm polysaccharides. Environ Microbial 15:334-346

Riise GC, Qvarfordt I, Larsson S et al (2000) Inhibitory effect of N-acetyl-L-cysteine on adherence of Streptococcus pneumoniae and Haemophilus influenzae to human oropharyngeal epithelial cells in vitro. Respiration 67:552-558

Roy R, Tiwari M, Donelli G, Tiwari V (2018) Strategies for combating bacterial biofilms: a focus on anti-biofilm agents and their mechanisms of action. Virulence 1 9(1):522-554

Santhi LS, Talluri VSSLP, Nagendra SY, Krishna E1R (2017). Nat Prod Chem Res 5:4.

Satheesh S, Ba-akdah MA, Al-Sofyani AA (2016) Natural antifouling compound production by microbes associated with marine macroorganisms - a review. Electron J Biotechnol 21:26-35

Satheesh S, Soniamby AR, Sunjaiy Shankar CV, Josephine Punitha SM (2012) Antifouling activities of marine bacteria associated with sponge (Sigmadocia sp.). J Ocean Univ China 11:354-360

Sayem S, Manzo ME, Ciavatta L, Tramice A, Cordone A, De Felice AZM, Varcamonti M (2011) Antibiofilm activity of an exopolysaccharide from a sponge-associated strain of Bacillus licheniformis. Microb Cell Fact 10:74

Sharad AA, Usupb G, Sahrani FK, Ahmad A (2016) Bioactivity of natural compounds produced by marine Alcaligenes faecalis as antimicrobial, antibiofilm formation and antibiocorrosion effect against Desulfovibrio sp. Isolated from crude oil fluid. Int J Advanc Scien Techn Res 6(6):134-148

Simoes M, Vieira MJ (2009) Persister cells in Pseudomonas fluorescens biofilms treated with a biocide. In: Proceedings of the international conference processes in biofilms: Fundamentals to applications. Davis, CA, USA.pp, pp 58-62

Teponno RB, noumeur SR, Helaly SE, Huttel S, Harzallah D, Stadler M (2017) Furanones and anthranilic acid derivatives from the endophytic fungus Dendrothyrium variisporum. Molecule 22(10): 1674

Trentin DS, Silva DB, Amaral MW, Zimmer KR, Silva MV, Lopes NP, Giordani RB, Macedo AJ (2013) Tannins possessing bacteriostatic effect impair Pseudomonas aeuroginosa. Plos one 8(6):e66257

Viju N, Punitha SMJ, Satheesh S (2018) Antifouling properties of bacteria associated with marine oyster Crassostrea sp. Thalasses. Doi.org/10.1007/s412 08-018-0095-9.

Viju N, Punitha SMJ, Satheesh S (2019) Antifouling potential of symbiotic marine bacterium Bacillus subtilus MUT:M15 associated with the cuttlefish Sepia sp. Indian J Geo-Mar Sci 48(05):685-697

Viju N, Satheesh S, Punitha SMJ (2016) Antibiofilm and antifouling activities of extracellular polymeric substances isolated from the bacteria associated with marine gastropod Turbo sp. Oceanol Hydrobiol St 45(1):11-19

Viju N, Satheesh S, Punitha SMJ (2017) Antifouling activities of antagonistic marine bacterium Pseudomonas putida associated with an octopus. Proc Natl Acad Sci India Sect B Biol Sci 87:1113-1124

Wagner-Dobler I, Beil W, Lang S et al (2002) Integrated approach to explore the potential of marine microorganisms for the production of bioactive metabolites. Adv Biochem Engin/Biotechnol 74:207-238

Watnick PI, Kolter R (1999) Steps in the development of a Vibrio cholerae El Tor biofilm. Mol Mcrobiol 34:586-595

Zhang MM, Wong FT, Wang Y, Luo S, Lim YH, Heng E et al (2017) CRISPR-Cas9 strategy for activation of silent Streptomyces biosynthetic gene clusters. Nat Chem Biol 13:607-609

Zheng CH, Ahmed K, Rikitomi N et al (1999) The effect of S-Carboxymethylcysteine and $\mathrm{N}$-acetyl-L-cysteine on the adherence of Moraxella catarrhalis to human pharyngeal epithelial cells. Microbiol immunol 43:107-113

\section{Publisher's Note}

Springer Nature remains neutral with regard to jurisdictional claims in published maps and institutional affiliations.

Ready to submit your research? Choose BMC and benefit from:

- fast, convenient online submission

- thorough peer review by experienced researchers in your field

- rapid publication on acceptance

- support for research data, including large and complex data types

- gold Open Access which fosters wider collaboration and increased citations

- maximum visibility for your research: over $100 \mathrm{M}$ website views per year

At BMC, research is always in progress.

Learn more biomedcentral.com/submissions 